*alls View/Frint Document Cover Sheet tow

This document was retrieved from the Boeing ISEARCH System.

Accession \#: D196071176

Document \#: SD-ETF-PCP-002

Title/Desc:

200 AREA ETF PROCESS CONTROL PLAN 95-001 


\begin{tabular}{|l|l|}
\hline $\begin{array}{l}\text { 2. To: (Receiving Organization) } \\
\text { Distribution }\end{array}$ & $\begin{array}{l}\text { 3. From: coriginating Organization) } \\
\text { LEF Process Engineering }\end{array}$ \\
\hline $\begin{array}{l}\text { 5. Proj./Prog./Dept./Div.: } \\
200 \text { Area Liquid Effluent } \\
\text { Facilities }\end{array}$ & 6. Cog. Engr.: \\
\hline
\end{tabular}

8. originator Remarks:

Project Control Plan, Run Plan, ETF Phase III Test

9. Equip./Component No.:

N/A

10. System/Bldg./Facility: $2025 \mathrm{E}$

11. Receiver Remarks:

12. Major Assm. Dwg. No.: N/A

13. Permit/Permit Application No.: $N / A$

14. Required Response Date: 10/06/95

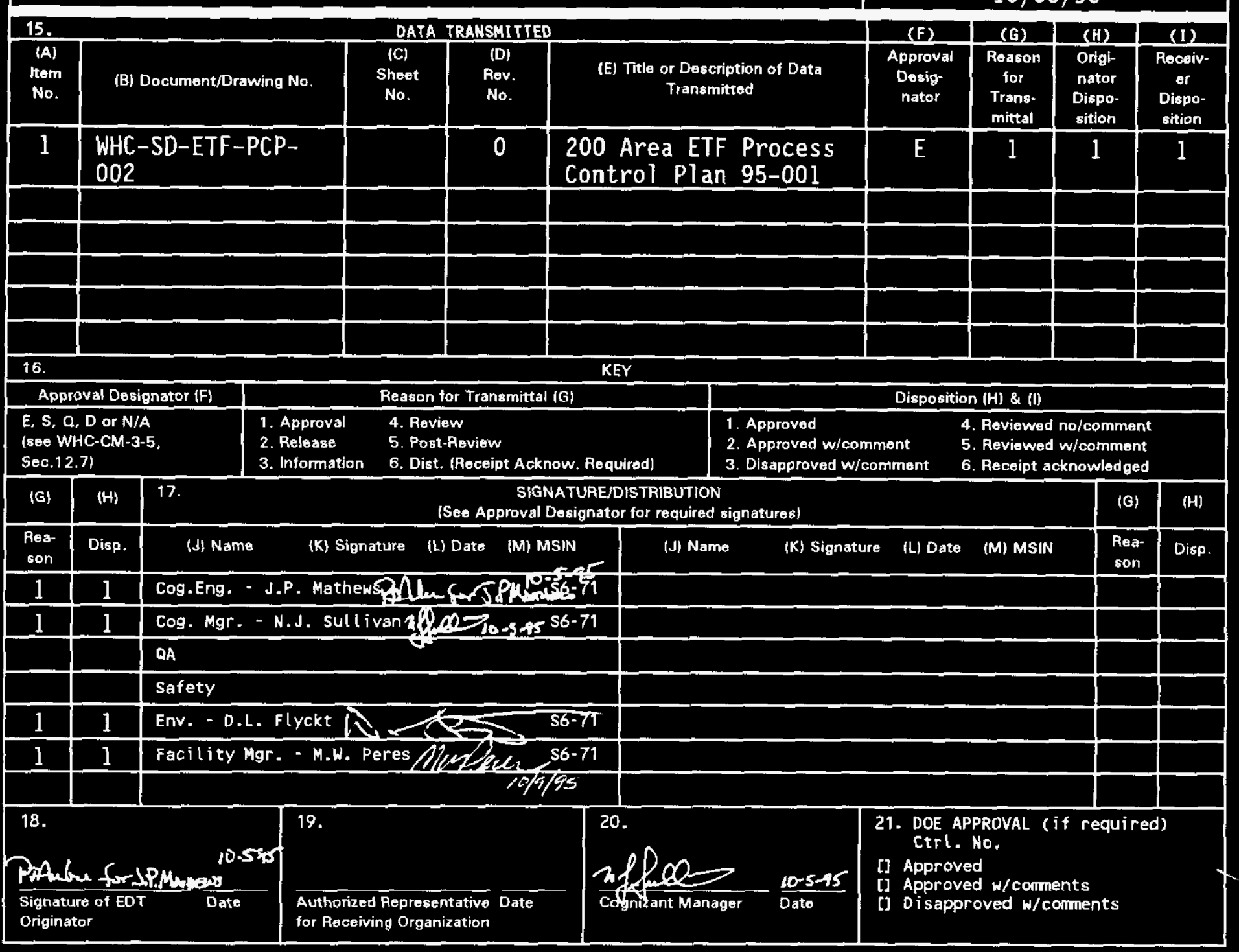

BD-7400-172-2(04/94) GEF097 


$$
\begin{aligned}
& \text { MVVII LITI GSA SIT } \\
& \text { MTVN }
\end{aligned}
$$




\section{RELEASE AUTHORIZATION}

Document Number: WHC-SD-ETF-PCP-002, REV 0

Document Title: 200 Area Effluent Treatment Facility Process Control Plan 95-001

Release Date: $\quad 10 / 10 / 95$

This document was reviewed following the procedures described in WHC-CM-3-4 and is:

\section{APPROVED FOR PUBLIC RELEASE}

WHC Information Release Administration Specialist:

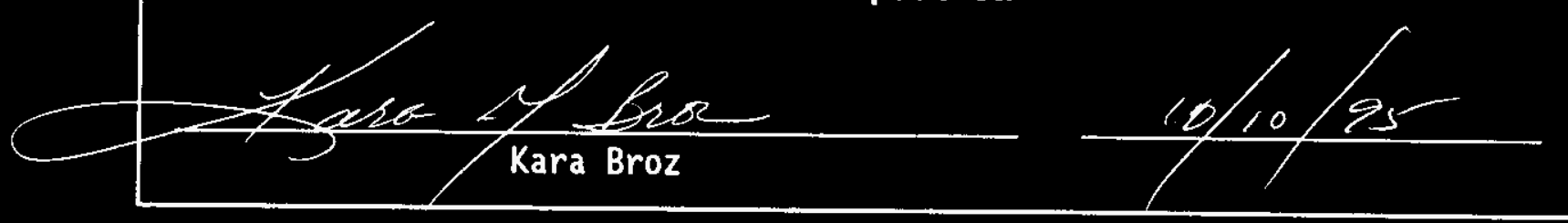

TRADENARK DISCLAINER. Reference herein to any specific commercial product, process, or service by trade name, trademark, manufacturer, or otherwise, does not necessarily constitute or imply its endorsement, recommendation, or favoring by the United States Government or any agency thereof or its contractors or subcontractors.

This report has been reproduced from the best available copy. Available in paper copy. Printed in the United States of America. To obtain copies of this report, contact:

Westinghouse Hanford Company - Document Control Services

P.0. Box 1970, Mailstop H6-08, Richland, WA 99352

Telephone: (509) 372-2420; Fax: (509) 376-4989 
THIS PAGE INTENTIONALLY LEET LLANK 


\begin{tabular}{|c|c|c|}
\hline $\begin{array}{l}\text { 2. Title } \\
200 \text { Area Effluent Treatment Facility Process } \\
\text { Control Plan } 95-001\end{array}$ & $\begin{array}{l}\text { 3. Number } \\
\text { WHC-SD-ETF-PCP-002 }\end{array}$ & $\begin{array}{c}\text { 4. Rev No. } \\
0\end{array}$ \\
\hline $\begin{array}{l}\text { 5. Key Words } \\
\text { ETF } \\
\text { Process Control Plan } \\
\text { Run Plan } \\
\text { C018H } \\
95-001\end{array}$ & $\begin{array}{l}\text { 6. Author } \\
\text { Name: J.P. Mathews } \\
\text { Signature } \\
\text { Organization/charge Code }\end{array}$ & $\frac{\text { Untews }}{6230 / \mathrm{A} 260 \mathrm{~N}}$ \\
\hline
\end{tabular}

7. Abstract

Provides initial run plan guidance for the 200 Area Effluent Treatment Facility in the treatment of Liquid Effluent Retention Facility waste during Phase III testing.

8. RELEASE STAMP

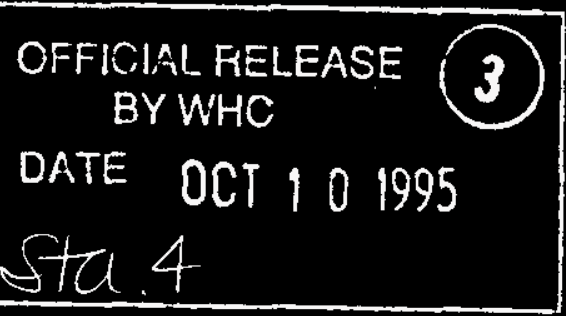


THIS PAGE INTENTIONALLY LETT BIANKR. 
TITLE:

Part A:

\section{ATTACHMENT 2, AUTHORIZATION BASES REVIEW FORM}

REFERENCE ITEM \# WHC-SD-ETF-PCP-002

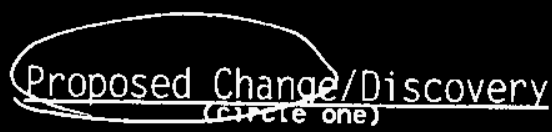

APPROVAL DESIGNATOR $E$

TITLE 200 Area ETF Process Control Plan 95-001

DESCRIPTION Describes overview, responsibilities, and process for initial ETF operation during Phase III Testing, while processing LERF P.C.

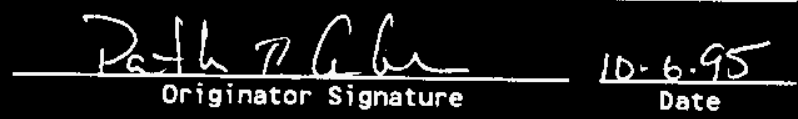

Part B:

Does the referenced item:
A. Increase risk from a hazard - to the workers 8 /or public beyond that previously analyzed, evaluated, and documented in the Authorization Bases?
No_ Yes/Maybe__
B. Reduce the reliability or effectiveness of features, controls, procedures, or processes used to mitigate hazards?
No 2 Yes/Maybe
c. Introduce a hazard not evaluated in the Authorization Bases?
D. Reflect new information on existing hazards beyond that currently
No 2 Yes/Maybe documented in the Authorization Bases?
No $\_$Yes/Maybe

(check one)

DETERMINATION BASES: Record complete justification and reference information below. Use Attachment 3 for continuations. Maintain with submittal package.

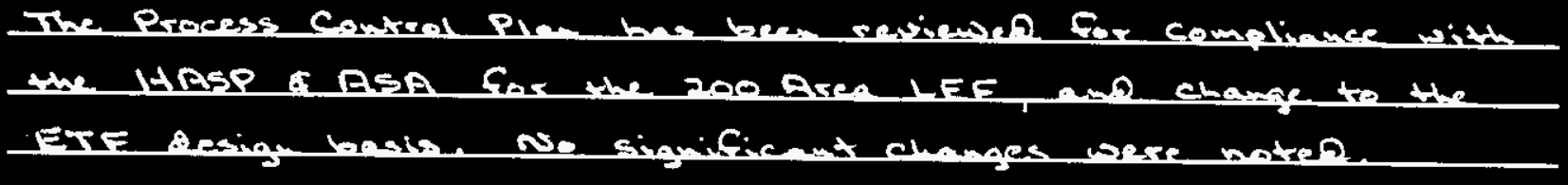

Potential Impact, No Impact. Item Remains Open ABR Closed

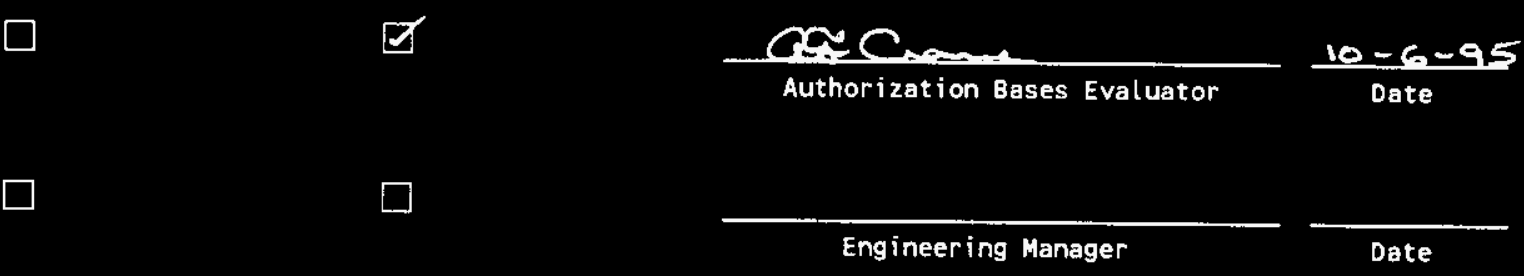

This document is a facility record when completed. Page $\perp$ of 1 


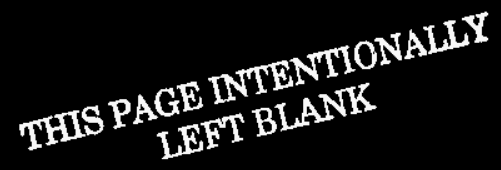


Document title:

Prepared by:

Approved by:

Approved by:

Approved by:
200 AREA EFFLUENT TREATMENT FACILITY

PROCESS CONTROL PLAN 95-0001

DrAmBLe for J.P. Markous

J. P. Mathews $\frac{10.5 .95}{\text { Date }}$ 200 Area Liquid Effluent Facilities Process Engineering

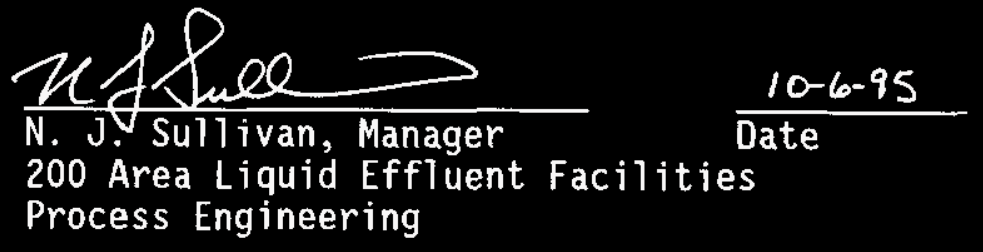
D. L. Flyckt, Manager 200 Area Liquid Effluent Facilities Environmental Engineering \& Regulatory Compliance

200 Area Liquid Effluent Facilities 
WHC-SD-ETF-PCP-002, Rev. 0

This page intentionally left blank. 
WHC-SD-ETF-PCP-002, Rev. 0

\title{
200 AREA EFFLUENT TREATMENT FACILITY PROCESS CONTROL PLAN
}

\author{
$\underline{95-001}$
}

October 05, 1995

WESTINGHOUSE HANFORD COMPANY 
WHC-SD-ETF-PCP-002, Rev. 0

This page intentionally left blank. 
TABLE OF CONTENTS

1.0 INTRODUCTION . . . . . . . . . . . ..... 1

1.1 SCOPE

1.2 EFFLUENT TREATMENT FACILITYY MISSION

1.3 BACKGROUND

2.0 PHASE III DEMONSTRATION TEST OBJECTIVES

2.1 DEPARTMENT OF ENERGY EXPECTATIONS.$\cdots 4$

2.2 STATE WASTE DISCHARGE PERMIT CRITERIA AND FINAL DELISTING CONDITIONS . . . . . . . . . . . . . . . . . 4

2.3 PHASE III TEST PROFILE . . . . . . . . . . . . 4

2.4 EFFLUENT TREATMENT FACILITY PHASE III TEST OBJECTIVE LIMITATIONS

3.0 LIQUID EFFLUENT RETENTION FACILITY CHARACTERIZATION . . . . . 5

3.1 BACKGROUND

3.2 METHODOLOGY

4.0 EFFLUENT TREATMENT FACILITY DISCHARGE PERMIT SUMMARY . . . . . . 6

4.1 BACKGROUND . . . . . . . . . . . . . . . . . . . 6

4.2 SAMPLE PRACTICES AND SCHEDULE .......... . 7

4.3 WASTE SAMPLING AND CHARACTERIZATION FACILITY LABORATORY

INTERFACE

4.4 SAMPLE RESULTS INTERPRETATION ......... 7

5.0 PHASE III DEMONSTRATION TEST PREREQUISITES . . . . . . . . 8

5.1 WESTINGHOUSE HANFORD COMPANY READINESS ASSESSMENT $\ldots . . .8$

5.2 EFFLUENT TREATMENT FACILITY STATUS $\ldots . . . . . . .8$

5.3 LIQUID EFFLUENT RETENTION FACILITY STATUS ......... 8

5.4 SAMPLE ANALYSIS LABORATORY SUPPORT . . . . . . . . . . . 9

5.5 STATE-APPROVED LAND DISPOSAL SITE ISOLATION VERIFICATION.$\cdots 9$

6.0 PHASE III DEMONSTRATION TEST . . . . . . . . . . . . . 9

6.1 MAIN TREATMENT TRAIN STARTUP $\ldots . . . . . . . . . . . .99$

6.2 SECONDARY TREATMENT TRAIN STARTUP $\ldots . . . . . . . . . . .10$

6.3 ACCEPTANCE CRITERIA . . . . . . . . . . . . . 10

7.0 REMAINING LIQUID EFFLUENT RETENTION FACILITY INVENTORY PROCESSING . 10

7.1 LIQUID EFFLUENT RETENTION FACILITY INVENTORY DEPLETION RUN • 10

8.0 REFERENCES ......................... 10 APPENDIXES

A PHASE III DEMONSTRATION TEST RUN PROFILE . . . . . . . . . . . 13

B LIQUID EFFLUENT RETENTION FACILITY BASIN SAMPLE ANALYSIS . . . . . 17 


\section{LIST OF TERHS}

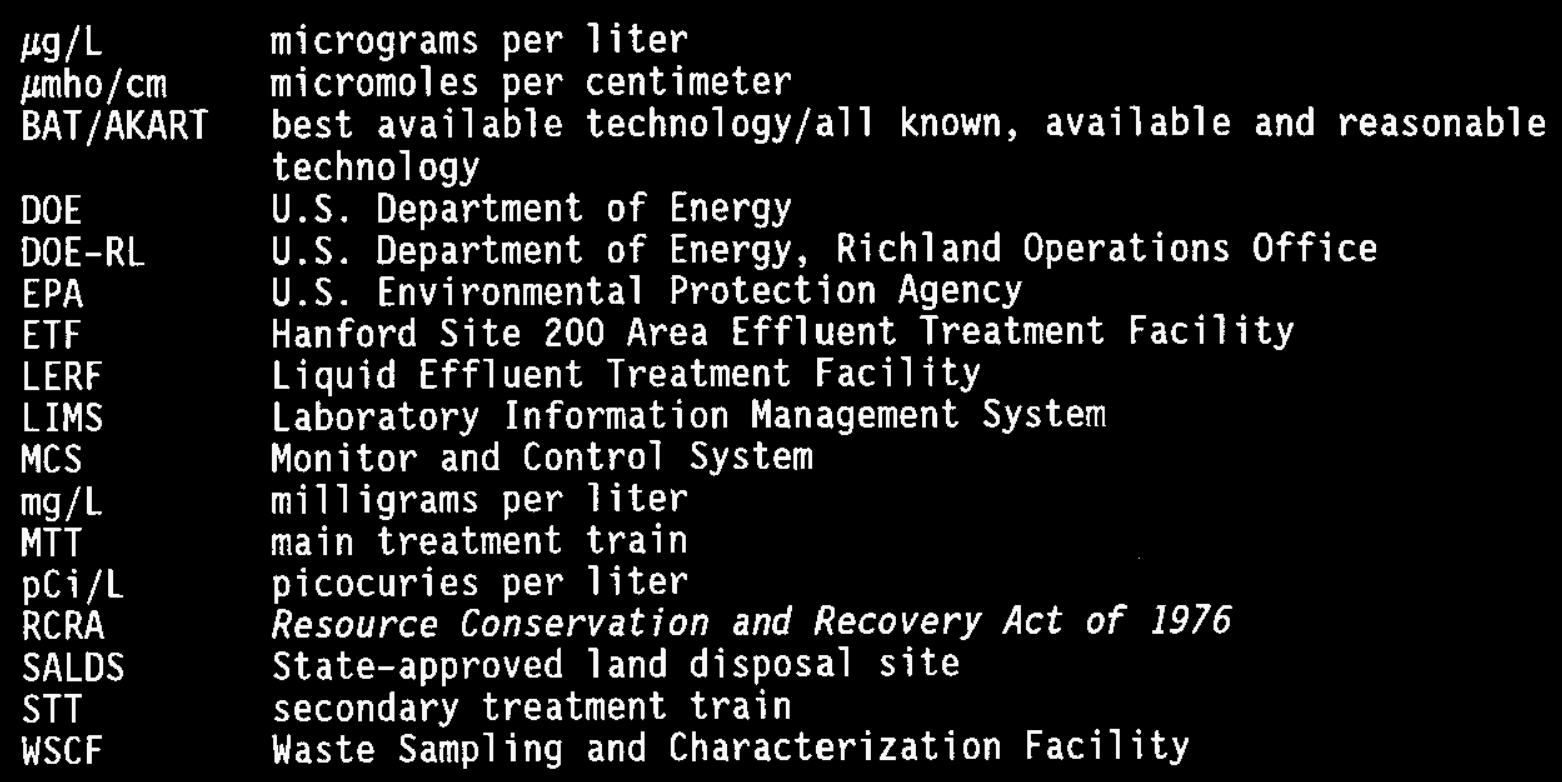




\subsection{INTRODUCTION}

\subsection{SCOPE}

This process control plan provides a general description of the initial startup and subsequent operation of the Hanford Site 200 Area Effluent Treatment Facility (ETF). Initial operation of the ETF is expected to start in November of 1995.

\subsection{EFFLUENT TREATMENT FACILITY MISSION}

The 200 Area Effluent Treatment Facility mission is to operate in a safe, cost effective, and environmentally compliant manner in order to fulfill the following commitments made with the United States Department of Energy, the Environmenta1 Protection Agency, and the State of Washington Department of Ecology:

- Fulfill Hanford Federal Facility Agreement and Consent Order No. DE 91NM-77 (Ecology et al., 1994) milestones to initiate ful1-scale hot operations of the ETF

- Support compliance with Hanford Federal Facility Agreement and Consent Order No. DE 91WM-77 (Ecology et al. 1994) to provide best available treatment technology to Hanford Phase I streams

The ETF will be operated such that the following major activities are successfully achieved:

- Transfer of Liquid Effluent Retention Facility (LERF) process source water to the ETF

- Reduce or remove contaminants in wastewater to levels that meet criteria established in the environmental permits

- Handle, package, and transport secondary solid waste in an environmentally compliant manner

- Discharge the treated effluent to a State-approved 1 and disposal site (SALDS).

\subsection{BACKGROUND}

The ETF is one of several facilities that are inter-related. Individual facility functions are summarized below, with additional emphas is given to the ETF. 
The primary source of ETF process inflow is the 242-A Evaporator located the 200 East Area. The evaporator concentrates radioactive and chemically hazardous liquid waste from various storage tanks and delivers the resulting process condensate to the LERF.

- Liquid Effluent Retention Facility (LERF)

The LERF is located in close proximity to both the 242-A Evaporator Facility and the ETF. The LERF is designed to retain the process condensate generated by the 242-A Evaporator, and consists of three identical surface-recessed holding basins. Each basin features primary and secondary polymer linings with floating cover, a leachate collection system, and a pumped transfer system. Each basin holds 6.5 million gallons.

\section{- $\quad$ ETF Load-in Facility}

The ETF Load-in Facility, located adjacent the ETF surge tank, consists of two 10,000 -gallon storage tanks, a tanker truck unloading station, and an underground transfer line connected to the ETF.

- Effluent Treatment Facility (ETF)

The ETF primary system components, known as the main treatment train (MTT), will purify low-level radioactive water containing small amounts of ammonia, inorganic and organic compounds.

The MTT process begins with a surge tank where the $\mathrm{pH}$ of the waste stream is adjusted by the $\mathrm{pH}$ adjustment system. Next, the waste stream is filtered to remove suspended solids greater than 2 microns in diameter. The process water is then injected with hydrogen peroxide and exposed to ultraviolet light, which destroys organic compounds.

Sulfuric acid is then added, which causes ammonium sulfate formation and converts carbonate ions to carbon dioxide for subsequent removal in the de-gas column. Decomposed hydrogen peroxide, which is harmful to process equipment, is removed via a granular activated charcoal medium.

A second filtration stage removes suspended solids greater than 0.5 microns in diameter. Next, dissolved carbon dioxide and other gases are removed by a degasification column, and the resulting gas stream is directed to the facility offgas system. The process water then passes through a two-stage reverse osmosis processor, which removes dissolved solids. Additional dissolved solids and radionuclides are next removed by a mixed-bed ion-exchange column. In the final step of the effluent treatment process, the process water is adjusted to a neutral pH value and discharged to a verification (holding) tank. 
The MTT process water is maintained in a verification tank until water quality sample analysis results confirm that release to a SALDS is permissible.

The ETF secondary treatment train (STT) provides for the collection and processing of the waste materials separated from the MTT process flow stream. Flow streams from MTT include: rough filter backwash, fine filter backwash, reverse osmosis retentate stream, and demineralizer regeneration waste.

Waste collected in either of the two secondary waste receiving tanks is $\mathrm{pH}$ adjusted to approximately 6 , then batch fed to the evaporator recirculation loop. The liquid waste is heated to vaporization temperature. The vapor passes through an entrainment separator where the resulting liquid droplets and solids are separated from the vapor phase. The vapor is compressed and passes through the evaporator feed heat exchanger where it releases its energy and condenses. The condensate is then returned to the surge tank. As water leaves the secondary waste stream in the vapor phase, the waste density within the evaporator increases to a pre-determined value that triggers a momentary discharge of waste concentrate to one of the two concentrate receiving tanks. Discharged material is then replaced in the evaporator by additional secondary waste receiving tank batch feed.

Secondary waste concentrate is pumped to the thin film dryer. The water fraction of the feed is evaporated by auxiliary steam heat and flows through the vapor outlet to a spray condenser. The spray condenser separates entrained vapor and solid waste and also condenses the vapor. The resulting distillate is returned to the surge tank. The powdered solid material is mechanically removed from the dryer cylinder walls and deposited into a hopper for final transfer into 55-gallon storage containers.

- State-Approved Land Disposal Site (SALDS)

The SALDS is a gravel-filled drainfield located in the 600 Area (north of the 200 West Area). The ETF effluent is discharged into the SALDS via underground piping from the ETF verification (holding) tank(s). The drainfield is designed to receive approximately 220,000 gallons of effluent daily.

The location of the SALDS was selected to allow the greatest travel time for tritium as it migrates from the disposal site to the aquifer that flows to the Columbia River. Groundwater modeling has indicated that tritium will decay to below established environmental criteria before it reaches the river. 


\subsection{PHASE III DEMONSTRATION TEST OBJECTIVES}

\subsection{DEPARTHENT OF ENERGY EXPECTATIONS}

Teynor (1995) defines specific criteria that the U.S. Department of Energy (DOE) requested the ETF demonstrate during the Phase III test. These criteria are 1 isted below.

- Demonstrate successful continuous operation of the ETF while processing waste material stored in the LERF. Flow rates shall be between 40 and $150 \mathrm{gallons} / \mathrm{minute}$. A minimum total volume of between 0.5 and 1.0 million gallons shall be processed.

- Demonstrate that treated effluent in the ETF verification tanks complies with State Waste Discharge Permit No. ST 4500 (Ecology 1995) and the Hazardous Waste Exclusion (Delisting) (EPA 1995).

- Demonstrate operation of the secondary treatment train, including the evaporator, thin film dryer, and drum handling systems.

\subsection{STATE WASTE DISCHARGE PERMIT CRITERIA AND FINAL DELISTING CONDITIONS}

Additional objectives of the Phase III test are to demonstrate compliance with applicable federal and state environmental 1aws. Section 4.0 presents a discussion of the environmental criteria or discharge limits established in the permits and regulatory documents associated with the LERF and ETF.

\subsection{PHASE III TEST PROFILE}

Phase III testing begins with the initial discharge of LERF water to the ETF and concludes when the water quality of a filled verification tank is demonstrated to comply with the permit criteria for discharge to the SALDS, as described in Section 4.0.

Operational objectives of the test are to demonstrate Operations ' capability to successfully operate the plant in accordance with established procedures at several MTT process flow rates and to process incoming LERF stream flow through the various systems so as to deliver quality water to the verification tanks. The planned MTT flow rate profile, spanning 40 gallons/minute to 150 gallons/minute, is shown in Appendix A.

\subsection{EFFLUENT TREATMENT FACILITY PHASE III TEST OBJECTIVE LIMITATIONS}

Phase III testing will commence with no inventory in any of the STT vessels. Considerable LERF feed stream must be processed through the MTT in order to build the STT waste inventory and produce solid waste. Calculations show that present LERF waste concentrations will make it necessary for $2.5 \times 10^{6}$ gallons 
of MTT water to be generated to build the STT concentrate tank inventory necessary for thin film dryer operation and associated demonstration of all STT test objectives. That volume is equivalent to 3.8 verification tanks.

Based on the fact that no more than two verification tanks (that have not been approved for disposal) are full at the same time, it will be necessary to delay demonstration of thin film dryer and drum handling system performance beyond initial verification tank discharge to SALDS. This time will be used to modify access to the dryer room (room 139) in order to downgrade the room classification from a "permit required confined space" :

A verification tank sample analys is will be completed for each filled tank. Compliance of the analys is results will be verified and approved by LEF management personnel and DOE prior to discharge to SALDS. If the sample results are unacceptable, the tank contents will be recycled through the MTT and discharged to another verification tank.

Although the test objective is to operate the facility on a nearly continuous basis during Phase III, it must be recognized that equipment malfunctions may occur that would require unplanned process shutdowns. The facility design operational efficiency of 72 percent, as stated in WHC (1994a), supports this approach.

\subsection{LIQUID EFFLUENT RETENTION FACILITY CHARACTERIZATION}

\subsection{BACKGROUND}

The 242-A Evaporator process condensate stored in LERF basins 42 and 43 was recently characterized, as is required before processing through the ETF. This characterization is necessary to meet several regulatory requirements, which include the following.

- Waste designation - Sufficient analytical data are needed to designate the process condensate before it is transferred to the ETF.

- Conditions for newly identified waste codes - Analytical data are needed to comply with the regulatory agreement on newly identified wastes.

- LERF liner compatibility - Data are needed to demonstrate that liner compatibility thresholds are not exceeded.

- Variability study - The State Waste Discharge permit requires variability data on ammonia, total Kjeldahl nitrogen, strontium-90, iodine-129, and tentatively identified organics.

- ETF treatment capability - Sufficient data are needed to support a review of and potential revision to the BAT/AKART evaluation for the ETF.

- Compliance with land disposal restrictions - Data are needed to determine if any residual solids buildup has occurred in the LERF. 
- Compliance with radiological inventory - The ETF has been determined to be a radiological facility. Sufficient radiological characterization data are needed to ensure that the ETF operates within the 1 imits specified in DOE Limited Standard 5502-94 (DOE 1994).

\subsection{METHODOLOGY}

At each of the seven available LERF sampling locations, sections of stainless steel tubing with quick-disconnects were inserted into the sample riser, and samples were collected at two random depths. Samples were obtained in a manner consistent with SW-846 procedures (EPA 1992).

The data from the characterization of LERF basins 42 and 43 are contained in Appendix B.

\subsection{EFFLUENT TREATMENT FACILITY DISCHARGE PERMIT SUMMARY}

\subsection{BACKGROUND}

The treated effluent from the ETF is classified under WAC 173-216 as industrial waste water, and a permit is required to discharge this effluent to the SALDS. The discharge permit (State Waste Discharge Permit No. ST 4500 [Ecology 1995]) identifies those constituents that must be monitored in the effluent and establishes numerical discharge criteria, or enforcement limits, that must be met to discharge the effluent.

The ETF effluent is also considered "1 isted hazardous waste" under the Resource Conservation and Recovery Act of 1976 (RCRA). Because of an exclusion, or delisting, from the RCRA hazardous waste management regulations granted by the U.S. Environmental Protection Agency (EPA), the effluent is no longer prohibited from 1 and disposal under the RCRA Land Disposal Restriction Program ( 40 CFR 268) and can be discharged to the SALDS. This exclusion was granted in response to a delisting petition that was submitted to the EPA. Like the State Waste Discharge Permit, the approved delisting also establishes numerical criteria, or delisting criteria, that must be met to discharge the treated effluent to the SALDS.

Additionally, the delisting approval requires that operating conditions, or parameters, that are essential to the quality of liquid effiuent that will be pumped into the ETF verification tanks, be monitored during ETF initial and subsequent verification testing. These operating conditions and the sampling results from the first three verification tanks must be submitted to EPA headquarters. 


\subsection{SAMPLE PRACTICES AND SCHEDULE}

Treated wastewater samples will be collected after final pH adjustment and before entry into the verification tanks. Two different sampling devices will be used. The first, a flow proportional sampler, will be used to collect samples for all analyses except volatile organic compounds. The second device is a zero-headspace time proportional sampler, which will be used to collect samples for volatile organic compound analyses.

If for any reason one or both of the composite samplers fail and cannot be repaired quickly, a representative sample will be collected manually from a sampling port on the verification tank recirculation line.

The ETF produces a powdered mixed waste that will be transferred to another treatment, storage and disposal unit for long-term storage and/or disposal. Because health and safety considerations preclude sampling the dry powder waste directly, slurry samples will be collected upstream of the thin film dryer. The concentrate tanks each have recirculation 1 ines to mix tank contents during $\mathrm{pH}$ adjustment and to prevent caking. A sample port in the recirculation line will be opened to collect samples directly into sample containers.

\subsection{WASTE SAMPLING AND CHARACTERIZATION FACILITY LABORATORY INTERFACE}

Samples of the treated wastewater will be transferred to the Waste Sampling and Characterization Facility (WSCF) laboratory. Some samples of the ETF concentrate may be transferred to the 222-S laboratory for analys is, if radionuclide levels warrant. All analyses will be performed in accordance with the ETF Waste Analys is Plan (WHC 1995b). Additionally, the analysis will be performed in accordance with the laboratory Quality Assurance Program Plans (WHC 1995C and 1995d) and the LEF Quality Assurance Project Plan (WHC 1995i).

Sample results will be "field verified" by the laboratory and reported on the Laboratory Information Management System (LIMS). The data can be directly accessed on LIMS or they can be transferred to the Liquid Effluent Monitoring Information System (LEMIS) for interpretation.

\subsection{SAMPLE RESULTS INTERPRETATION}

The discharge criteria from the State Waste Discharge Permit (Ecology 1995) and the approved delisting are summarized in an attachment to OSP-60H-001 "Verification System Operations (WHC 1995f)." This document describes the procedure for ensuring that these criteria are met in the verification tanks before the effluent is discharged to the SALDS.

Appendix B compares the characterization data for basins 42 and 43 against the ETF release 1 imits. 


\subsection{PHASE III DEMONSTRATION TEST PREREQUISITES}

\subsection{WESTINGHOUSE HANFORD COMPANY READINESS ASSESSMENT}

The Readiness Assessment is a DOE administrative process used to assure that a contractor is prepared and capable to successfully operate a DOE facility. The assessment is a contractor self-evaluation of specific activities as set forth in DOE Order 5480.31 (DOE 1995) and U1mer (1995).

The Readiness Assessment process must be successfully completed and accepted by Westinghouse Hanford Company (WHC) management, followed by issuance of a "memorandum-to-proceed" by the ETF manager to the U.S. Department of Energy Richland Operations Office (DOE-RL) Startup Authority, signifying that readiness has been achieved. Additionally, the memorandum will include a recommendation to DOE-RL that Phase III testing be initiated, to which DOE-RL will concur, if satisfied with the Readiness Assessment results. Upon resolution of all pre-start items identified in the WHC and DOE-RL Readiness Assessment, the DOE-RL approval authority will authorize full operations startup of the ETF, including discharge to the SALDS.

Phase III testing will be conducted in accordance with this process control plan, as an attachment to a long-term standing order issued per WHC (1994b), and applicable plant operating procedures.

Upon full startup authorization from DOE-RL, the 200 Area LEF Facility Manager will authorize the Operations Manager (by signing the applicable long-term standing order) to initiate unrestricted operation.

\subsection{EFFLUENT TREATMENT FACILITY STATUS}

Prior to introduction of LERF water to the ETF, all plant systems will be prepared for operation in accordance with applicable Plant Maintenance Procedures and Plant Operating Procedures. Specific systems will be filled to required operating levels using existing verification tank water inventory.

The Monitor and Control System (MCS) has previously been energized, operated, and remains in a standby operational mode.

\subsection{LIQUID EFFLUENT RETENTION FACILITY STATUS}

The 242-A Evaporator process condensate inventory presently stored in LERF totals approximately 9.4 million gallons; 3.2 million gallons are in basin 42 and 6.2 million gallons are in basin 43 .

As discussed earlier, a LERF basins 42 and 43 sample analys is has been completed by the WSCF. The results indicate that the LERF water is acceptable for discharge to the ETF. LERF sample results and corresponding SALDS discharge limits are shown in Appendix B. 
A radionuclides inventory calculation, using LERF sample analys is data, shall be performed in accordance with WHC (1995j) prior to the release of existing LERF inventory to the ETF.

\subsection{SAMPLE ANALYSIS LABORATORY SUPPORT}

The WSCF is available to support the ETF sampling and analys is activity. The 222-S Laboratory may be used for solid mixed waste analys is if radionuclide activity levels prohibit analysis elsewhere.

\subsection{STATE-APPROVED LAND DISPOSAL SITE ISOLATION VERIFICATION}

To assure that a verification tank cannot be discharged to the SALDS prior to water quality approval, the verification tank discharge manifold piping isolation valves $60 \mathrm{H}-103$ and $60 \mathrm{H}-104$, immediately downstream of transfer pumps $60 \mathrm{H}-\mathrm{P}-2 \mathrm{~A}$ and $60 \mathrm{H}-\mathrm{P}-2 \mathrm{~B}$, respectively, will be closed and administratively controlled in accordance with WHC (1994b).

\subsection{PHASE III DEMONSTRATION TEST}

\subsection{MAIN TREATMENT TRAIN STARTUP}

P1 ant operating procedures OSP-060-001, MTT Operation (WHC 1995a) or 0SP-60-002, Integrated MTT Operation (WHC 1995e) will be used (individually or in combination) to initiate the MTT startup. Utility support systems are verified to be in service as listed in the MTT plant operating procedure(s). Further startup prerequisites include confirmation of required tank levels, reverse osmosis bank preparation, polisher preparation, and that a secondary waste receiving tank is available. The Monitor and Control System (MCS) is continuously powered up and features an uninterruptable power supply; thus, the system is already in service.

When all MTT preparatory steps are complete, the MCS permissive light illuminates, indicating MTT operation may be initiated on the MCS. The initial pre-selected influent flow rate will be approximately 40 gallons/minute with planned MTT shutdown and restart for an additional flow increase to the maximum design value of 150 gallons/minute. Following an additional shutdown, the MTT will be restarted at a nominal 90- to 120-gallon/minute flow rate for the duration of the Phase III test. Appendix A shows the overall Phase III demonstration test run profile. The overall Phase III test is expected to require approximately three days to complete. 


\subsection{SECONDARY TREATMENT TRAIN STARTUP}

The secondary waste receiving tank(s) will initially be empty and prepared to receive waste material in accordance with 0SP-60I-008 (WHC 1995h) prior to MTT startup. The evaporator will be started in accordance with 0SP-60I-003

(WHC $1995 \mathrm{~g}$ ) when sufficient receiving tank waste inventory is generated. The planned processing flow rate is approximately 18 gallons/minute. As stated previously, the thin film dryer and drum handling system will not be operated during the Phase III test, but will be operated during the remaining LERF inventory processing.

\subsection{ACCEPTANCE CRITERIA}

Phase III test acceptance criteria shall be the successful demonstration that the facility can produce acceptable quality water at the prescribed flow rates in a reasonably continuous manner. The verification tank water quality shall conform to the release criteria set forth in State Waste Discharge Permit No. 4500 (Ecology 1995) and the Hazardous Waste Exclusion (Del isting) (EPA 1995).

\subsection{REMAINING LIQUID EFFLUENT RETENTION FACILITY INVENTORY PROCESSING}

\subsection{LIQUID EFFLUENT FACILITY INVENTORY DEPLETION RUN}

ETF will commence processing the remaining LERF inventory of approximately 8.7 million gallons of water at a $40-$ to $150-$ gallon/minute flowrate following satisfactory conclusion of the Phase III test, DOE-RL readiness approval, and completion of the planned installation of the drum handling room horizontal access.

\subsection{REFERENCES}

40 CFR 268, "Land Disposal Restrictions," Code of Federal Regulations, as amended.

DOE, 1990, Radiation Protection of the Public, DOE Order 5400.5, U.S. Department of Energy, Washington, D.C.

DOE, 1993, Startup and Restart of Nuclear Facilities, DOE Order 5480.31, U.S. Department of Energy, Washington, D.C.

DOE, 1994, Hazard Baseline Document, DOE-EM-STD-5502-94, U.S. Department of Energy, Washington, D.C.

Ecology, EPA and DOE, 1994, Hanford Federal Facility Agreement and Consent Order, as amended, Washington State Department of Ecology, U.S. Environmental Protection Agency, and U.S. Department of Energy, 01ympia, Washington. 
Ecology, 1995, State Waste Discharge Permit No. 4500 for 200 Area Effluent Treatment Facility, Hanford Facility, Washington State Department of Ecology, 01ympia, Washington.

EPA, 1992, Test Methods for Evaluating Solid Waste, 3rd Edition, EPA-SW-846 as derived from EPA-600/4-79-019, U.S. Environmental Protection Agency, Office of Solid Waste and Emergency Response, Washington, D.C.

EPA, 1995, "Final Approval for Delisting to U.S. Department of Energy," 60 FR 31115, Federal Register, Vo1. 60, beginning p. 31115, June 13, U.S. Environmental Protection Agency, Washington, D.C.

Resource Conservation and Recovery Act of 1976 (RCRA), 42 USC 6901, et seq.

Teynor, T. K., 1995, Processing of Liquid Effluent Retention Facility (LERF) Material in the 200 Area Effluent Treatment Facility - Phase III Testing, (letter 95-LEP-149 to President of Westinghouse Hanford Company, July 14), U.S. Department of Energy, Richland Operations Office, Richland, Washington.

U1mer, F. J., 1995, $200 E$ Area Effluent Treatment Facility Readiness Assessment Plan, WHC-SD-C018H-RRR-001, Rev. 0, Westinghouse Hanford Company, Richland, Washington.

WAC 173-216, 1991, "State Waste Discharge Permit Program," Washington Administrative Code, as amended, Washington State Department of Ecology, 01 ympia, Washington.

WHC, 1994a, ETF Design/Construction Specification V-C018HC1-001, Rev. 0Q, paragraph 1.5.5.3., Westinghouse Hanford Company, Rich1and, Washington.

WHC, 1994b, 200 Area LEF Conduct of Operations, WHC-IP-0932, Rev. 0, Westinghouse Hanford Company, Richland, Washington.

WHC, 1995a, MTT Operation, Plant Operating Procedure 0SP-060-001, Rev. 0, Westinghouse Hanford Company, Richland, Washington.

WHC, 1995b, Waste Analysis Plan for the 200 Area Effluent Treatment Facility and the Liquid Effluent Retention Facility, WHC-SD-EN-WAP-001, Rev. 0, Westinghouse Hanford Company, Richland, Washington.

WHC, 1995c, Quality Assurance Program Plan for the Waste Sampling and Characterization Facility, WHC-SD-CP-QAPP-0017, Westinghouse Hanford Company, Richland, Washington.

WHC, 1995d, 222-S Laboratory Quality Assurance Plan, WHC-SD-CP-QAPP-016, Rev. 1, Westinghouse Hanford Company, Richland, Washington.

WHC, 1995e, Integrated MTT Operation, Plant Operating Procedure 0SP-060-002, Rev. 0, Westinghouse Hanford Company, Richland, Washington.

WHC, 1995f, Verification System Operations, P1ant Operating Procedure 0SP-60H-001, Westinghouse Hanford Company, Richland, Washington. 
WHC, 1995g, Evaporator System Operation, Plant Operating Procedure 0SP-60I-003, Westinghouse Hanford Company, Richland, Washington.

WHC, 1995h, Secondary Waste Receiving Tank Operation, Plant Operating Procedure 0SP-60I-008, Westinghouse Hanford Company, Richland, Washington.

WHC, 1995i, 200 Area Liquid Effluent Facjlities Quality Assurance Program P7an, WHC-SD-LEF-QAPP-001, Rev. 10A, West inghouse Hanford Company, Richland, Washington.

WHC, 1995j, 200 Area Liquid Effluent Facilities Radionuclide Inventory Management Plan, WHC-IP-0931, Section 12, Rev. 0, Westinghouse Hanford Company, Richland, Washington. 
WHC-SD-ETF-PCP-002, Rev. 0

APPENDIX A

PHASE III DEMONSTRATION TEST RUN PROFILE 
WHC-SD-ETF-PCP-002, Rev. 0

This page intentionally left blank. 


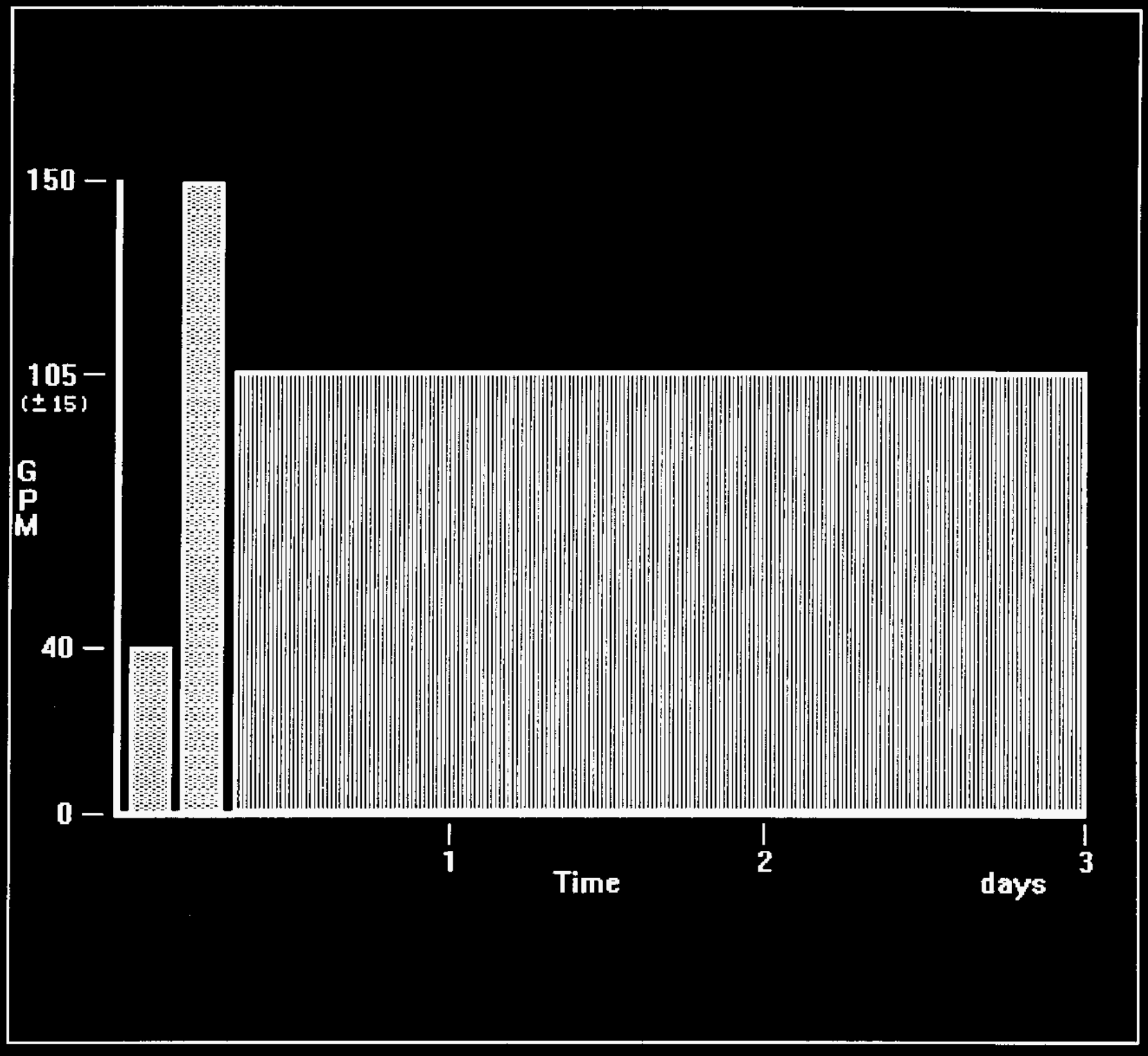

Note: The 40- and 150-gallon/minute (GPM) segments of this testing will last between 2 and 4 hours each. If the required

2-hour minimum segments at nominal flow are interrupted, the test is restarted for that segment. 
WHC-SD-ETF-PCP-002, Rev, 0

This page intentionally left blank. 
WHC-SD-ETF-PCP-002, Rev. 0

APPENDIX B

LERF BASIN SAMPLE ANALYSIS 
WHC-SD-ETF-PCP-002, Rev. 0

This page intentionally left blank. 
WHC-SD-ETF-PCP-002, Rev. 0

LERF BASIN 42 SAYPLE ANALYSTS (2 pages)

Paraneter

VOLATLE BRGAWIC CO, BUWDS

beotons:

benzsol

1. Butsonol

Carton setrachl or to de

Chlorobenzens

Chlorotorm

1.20 Dichloroe thane

1) 10 oi ahlorow thene.

2-butathone

Hexons

Tetradutoroethere

Tetrabydrofuran

olvenes

$1,1,1$ - Hichloroethane

$1,1,2-1$ r ichloroe thane

Inteht,orocthene

vind chloride

SENIVOLATILE BREANIC CCNPOUNDS

Acetophenone

Bentyl alcohol.

Cresol

1, 4-0ichlorobenzene

$\mathrm{N}-\mathrm{Nitrosodimethylamine}$

Di-n-octyl phthalate

Hexachl loroethane

Naph thalene

Tributyl phosthate

TOTAL METALS

Ant imony

Arsenic

Barium

Beryll itm

Cackniun

Chromiun

Copper

Lead

Mercury

Nickel

Selenium

silver

Vanadium

Zinc units

Actual paraneter
value

Release

ifits

$1 \mathrm{mit}$ sotres

(see nottes)

Actuat < Limit

$Y / N$

\begin{tabular}{lll}
40,000 & 2 & YES \\
\hline
\end{tabular}

4Q2 2

sqda

$42 / \mathrm{k}$

and.

$42 / 2$

$1 \mathrm{LOL}$

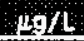

$30 / \mathrm{L}$

401 .

19\%

4x/L.

$49 / \mathrm{L}$

Me/L

Ho/L.

HO/L.

UOAL

Hola

$\square$

\begin{tabular}{|l|l}
\hline$\mu g / L$ & $3 \mathrm{~J}$ \\
\hline$\mu g / L$ & $4 \mathrm{~J}$ \\
\hline$\mu / L$ & $5 \mathrm{U}$ \\
\hline$\mu / L$ & $5 \mathrm{U}$ \\
$\mu \mathrm{g} / \mathrm{L}$ & 6 \\
$\mu \mathrm{g} / \mathrm{L}$ & $5 \mathrm{U}$ \\
\hline$\mu g / \mathrm{L}$ & $5 \mathrm{U}$ \\
\hline$\mu g / \mathrm{L}$ & $5 \mathrm{U}$ \\
$\mu \mathrm{g} / \mathrm{L}$ & $5 \mathrm{U}$ \\
\hline
\end{tabular}

$\mu g / L$

ipg/L

$\mu \mathrm{g} / \mathrm{L}$.

$\mu g / L$

$\mu g / L$

$\mu \mathrm{g} / \mathrm{L}$.

$\mu g / L$

$\mu \mathrm{g} / \mathrm{L}$

$\mu \mathrm{g} / \mathrm{L}$

$\mu \mathrm{g} / \mathrm{L}$

$\mu \mathrm{g} / \mathrm{L}$

Hg/L

$\mu g / L$.

$\mu g / L$

$\mu g / L$

\begin{tabular}{|c|c|}
\hline $36 \mathrm{U}$ \\
\hline 0 \\
\hline $4 \mathrm{U}$ \\
\hline $4 \mathrm{U}$ \\
\hline $\mathrm{JU}$ \\
\hline & $5 \mathrm{U}$ \\
\hline 0 \\
\hline 0.2 \\
\hline $13 \mathrm{U}$ \\
\hline $1.6 \mathrm{~J}$ \\
\hline $5 \mathrm{U}$ \\
\hline $9 \mathrm{U}$ \\
\hline 23 \\
\hline
\end{tabular}

\begin{tabular}{|c|c|}
\hline 10 \\
\hline 100,000 \\
20,000 \\
750 \\
\hline 20 \\
7,000 \\
\hline 60 \\
\hline 10,000 \\
\hline 200 \\
\hline 60 \\
\hline 15 \\
\hline 20,000 \\
\hline 40 \\
\hline 7.5 \\
\hline 20 \\
\hline 70 \\
\hline 38 \\
\hline 2 \\
\hline 1000 \\
\hline 500 \\
\hline 2,000 \\
\hline 2,000 \\
\hline 100,000 \\
\hline
\end{tabular}

Yes

YES

YES

YES

YES

YES

YES

YES

YES

ES

YES

YES

YES

YES

YES

YES

YES

YES

YES

YES

YES

YES

YES 


\section{LERF BASTM 42 SAMPLE ANALYSTS (2 pages)}

\begin{tabular}{|c|c|c|c|c|c|}
\hline Paranter: & Bnts & $\begin{array}{c}\text { Actual paraneter } \\
\text { value }\end{array}$ & $\begin{array}{l}\text { Relesse } \\
\text { limits }\end{array}$ & $\begin{array}{l}\text { Lifit source } \\
\text { (see notes) }\end{array}$ & $\begin{array}{c}\text { Actual }<\text { Limit } \\
Y / N\end{array}$ \\
\hline \multicolumn{6}{|l|}{ ANrois } \\
\hline Eluoribs & ind & 0.32 & 40 & 2 & YES \\
\hline Litratse & $\mathrm{ng} / \mathrm{L}$ & 0.11 & 0.100 & 1 & No \\
\hline Hitritse & $1201 \mathrm{~L}$ & $0.0 \mathrm{U}$ & 0.100 & 1 & YES \\
\hline sulfote & $H=1 L$ & $0.26 \mathrm{U}$ & 10 & 1 & YES \\
\hline \multicolumn{6}{|l|}{ RADTOWUICL TOES } \\
\hline Bross atspa & pcill. & $0.0388 \mathrm{~J}$ & 1.2 & 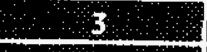 & no \\
\hline Gross Beta & $201 / 4$ & 108 & 40 & 3 & no \\
\hline $\operatorname{cen} 1011-144$ & pej/L. & $32.5 \mathrm{~J}$ & 280 & 3 & YES \\
\hline Cestien 134 & $\mathrm{pci} / \mathrm{L}$ & $5 \mathrm{~J}$ & 80 & 3 & YES \\
\hline Cessiunalez & peil & 637 & 120 & 3 & No \\
\hline Cobal 280 & $\mathrm{BCi} / \mathrm{L}$ & $5 \mathrm{~J}$ & 200 & 3 & YES \\
\hline Europil -154 & $\mathrm{pct} / \mathrm{L}$ & $15 \mathrm{~J}$ & 800 & 3 & YES \\
\hline Eurapien- 155 & $\mathrm{pei} / \mathrm{L}$ & $15 \mathrm{~J}$ & 4,000 & 3 & YES \\
\hline Wiobicin-o/4 & pcia & $3.89 \mathrm{~J}$ & 1,200 & 3 & YES \\
\hline Ruthenifon 103 & $p c i / L$ & $5.78 \mathrm{~J}$ & 2,000 & 3 & YES \\
\hline Butheriton-106 & pci $t:$ & $90 \mathrm{~J}$ & 240 & 3 & YES \\
\hline strontien 90 & pcill & 42.7 & 40 & 3 & No \\
\hline Tin-113. & $\mathrm{pCi} / \mathrm{L}$ & $5 \mathrm{~J}$ & 2,000 & 3 & YES \\
\hline Iritilu & pci/L: & $6,860,000$ & $\therefore$ & $=$ & $\cdots$ \\
\hline \multicolumn{6}{|l|}{ OTHER AMLYSES } \\
\hline Almonia & $\operatorname{mig} / \mathrm{L}$ & 200 & 0.830 & 1 & No \\
\hline Nitrogen K jelodahl total & $\mathrm{mg} / \mathrm{L}$. & 180 & 0.600 & 1 & No \\
\hline Cyanide & $\mathrm{mg} / \mathrm{k}$ & 0 & 2 & 2 & YES \\
\hline Total dissolved sol ids & $\mathrm{mg} / \mathrm{L}$ & 0 & 380 & 1 & YES \\
\hline Iotal or anic carbon & $\mathrm{mg} / \mathrm{L}$ & 5.6 & 1.1 & 1. & No \\
\hline Lotal susperided solids & $\mathrm{mg} / \mathrm{L}$ & 0.2 & 4 & 1 & YES \\
\hline Specific conductivity & untio/cm. & 160.3 & $\cdots$ & - & $\cdots$ \\
\hline
\end{tabular}

NOTES: (1) Ecology Permit No. ST 4500, dated 06/26/95 (Ecology 1995)

(2) EPA Delisting Approval, dated 6/7/95 (EPA 1995)

(3) DOE Order 5400.5 (4\% of derived concentration guides) (DOE 1990)

$\mathrm{U}=$ undetected

$\mathrm{J}=$ estimate

SAMPLE NUMBER: L00096 SAMPLE DATE $8 / 3 / 95$

RAD SAMPLE NUMBER: L00111 SAMPLE DATE $\underline{\underline{8 / 3 / 95}}$ 


\begin{tabular}{|c|c|c|c|c|c|}
\hline \multicolumn{6}{|c|}{ LERF BASTH 43 SAMPLE ANALYSTS (2 pages) } \\
\hline Paraineter & Units & $\begin{array}{c}\text { Actual parameter } \\
\text { value }\end{array}$ & $\begin{array}{l}\text { Release } \\
\text { limits }\end{array}$ & $\begin{array}{l}\text { tuit source } \\
\text { (see notes) }\end{array}$ & $\underset{Y / N}{\text { Actual }<\text { Limit }}$ \\
\hline \multicolumn{6}{|c|}{ VOLATHE OBGANIC GOWPOUISS } \\
\hline Actosis. & 1292 & 200 & 40,000 & 2. & YES \\
\hline Benzene: & $12 \mathrm{~g} / \mathrm{L}$ & $1 \mathrm{U}$ & 5 & 1 & YES \\
\hline 1 Bttanal. & eq/2. & $1 \mathrm{U}$ & 40,000 & 2. & YES \\
\hline Casbon tetrachloride. & 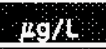 & $1 \mathrm{U}$ & 5 & 1 & YES \\
\hline Chlorobenzens. & $\mu / 21$ & $1 \mathrm{U}$ & 1,000 & 2. & YES \\
\hline chlorotasn & $\underline{H a / L}$ & $1 \mathrm{U}$ & 5 & 1 & YES \\
\hline 1,2,ouchloroesthane & go/L & $1 \mathrm{u}$ & 50 & 2 & YES \\
\hline 1, 1 - Dichloroethene. & 10/11. & $1 \mathrm{U}$ & 70. & 2 & YES \\
\hline 2. Butranone & $10 \Omega$ & 3 & 200,000 & 2 & YES \\
\hline Mexoras & $\mu 2 / 2$ & 10 & 30,000 & 2 & YES \\
\hline Tetrachiorosthene & gg/L & $1 \mathrm{U}$ & 5 & 1. & YES \\
\hline Ietrabydrotiran & ge/2. & 150 & 100 & 1 & No \\
\hline Toluene & $49 / L$ & $1 \mathrm{U}$ & 10,000 & 2 & YES \\
\hline $1,1,1$, it the lorosthane & $\mu \mathrm{g} / \mathrm{L}$ & $1 \mathrm{U}$ & 2,000 & 2 & YES \\
\hline 1,1,2-Irichloroethane. & HO/L & $1 \mathrm{U}$ & 5 & 2 & YES \\
\hline Intehloroethene & $2: 12$ & $1 \mathrm{U}$ & 50. & 2. & YES \\
\hline Vind chloridos & gg/L & $1 \mathrm{U}$ & 20. & 2 & YES \\
\hline \multicolumn{6}{|c|}{ SENIVOLATILE OREANIC COMPOUNDS } \\
\hline Acetophenone & $2 / L$ & $3 \mathrm{~J}$ & 10 & 1 & YES \\
\hline Benzyl alcobol & $\mu \mathrm{g} / \mathrm{L}$ & $5 \mathrm{U}$ & 100,000 & 2 & YES \\
\hline Eresol & $\mu \mathrm{g} / \mathrm{L}$ & $5 \mathrm{U}$ & 20,000 & 2 & YES \\
\hline 1,4-Diehlorobenzene & $\mu \mathrm{g} / \mathrm{L}$ & $5 \mathrm{U}$ & 750 & 2 & YES \\
\hline N-Nitrosodimathylamine & Hg/L. & $4 \mathrm{~J}$ & 20 & 1 & YES \\
\hline Di-n-octyl ohthalate & $\mu \mathrm{g} / \mathrm{L}$ & 40 & 7,000 & 2 & YES \\
\hline Hexachloroethane & $39 / \mathrm{L}$ & $5 \mathrm{U}$ & 60 & 2 & YES \\
\hline Naphthalene & $\mu g / L$ & $5 \mathrm{U}$ & 10,000 & 2 & YES \\
\hline Iributyt phosphate & $\mu \mathrm{g} / \mathrm{L}$ & 1100 & 200 & 2 & NO \\
\hline \multicolumn{6}{|l|}{ TOTAL METALS } \\
\hline Antimony & $\mu g / \mathrm{L}$ & $36 \mathrm{U}$ & 60 & 2 & YES \\
\hline Arsenic & gg/L & 0 & 15 & 1 & YES \\
\hline Barium. & $\mu \mathrm{g} / \mathrm{L}$ & $4 U$ & 20,000 & 2 & YES \\
\hline Berylliun & $\mu \mathrm{g} / \mathrm{L}$ & 40 & 40 & 1 & YES \\
\hline Cadnium & $\mu \mathrm{g} / \mathrm{L}$ & 0 & 7.5 & 1 & YES \\
\hline Chromium & $\mu \mathrm{g} / \mathrm{L}$ & $0 \mathrm{U}$ & 20 & 1 & YES \\
\hline Copper & $\mu \mathrm{g} / \mathrm{L}$ & $5 \mathrm{U}$ & 70 & 1 & YES \\
\hline Lead: & $\mu q / L$ & 1.1 & 38 & 1 & YES \\
\hline Mercury & $\mu g / L$ & $<0.2$ & 2 & 1 & YES \\
\hline Nickel & $\mu g / L$ & $13 U$ & 1000 & 2 & YES \\
\hline Selenium & $\mu q / L$ & 0 & 500 & 2 & YES \\
\hline silver & $\mu g / L$ & $5 \mathrm{U}$ & 2,000 & 2 & YES \\
\hline Vanadium & $\mu \mathrm{g} / \mathrm{L}$ & 90 & $2,0,00$ & 2 & YES \\
\hline Zinc & $\mu g / L$ & 18 & 100,000 & 2 & YES \\
\hline
\end{tabular}


WHC-SD-ETF-PCP-002, Rev. 0

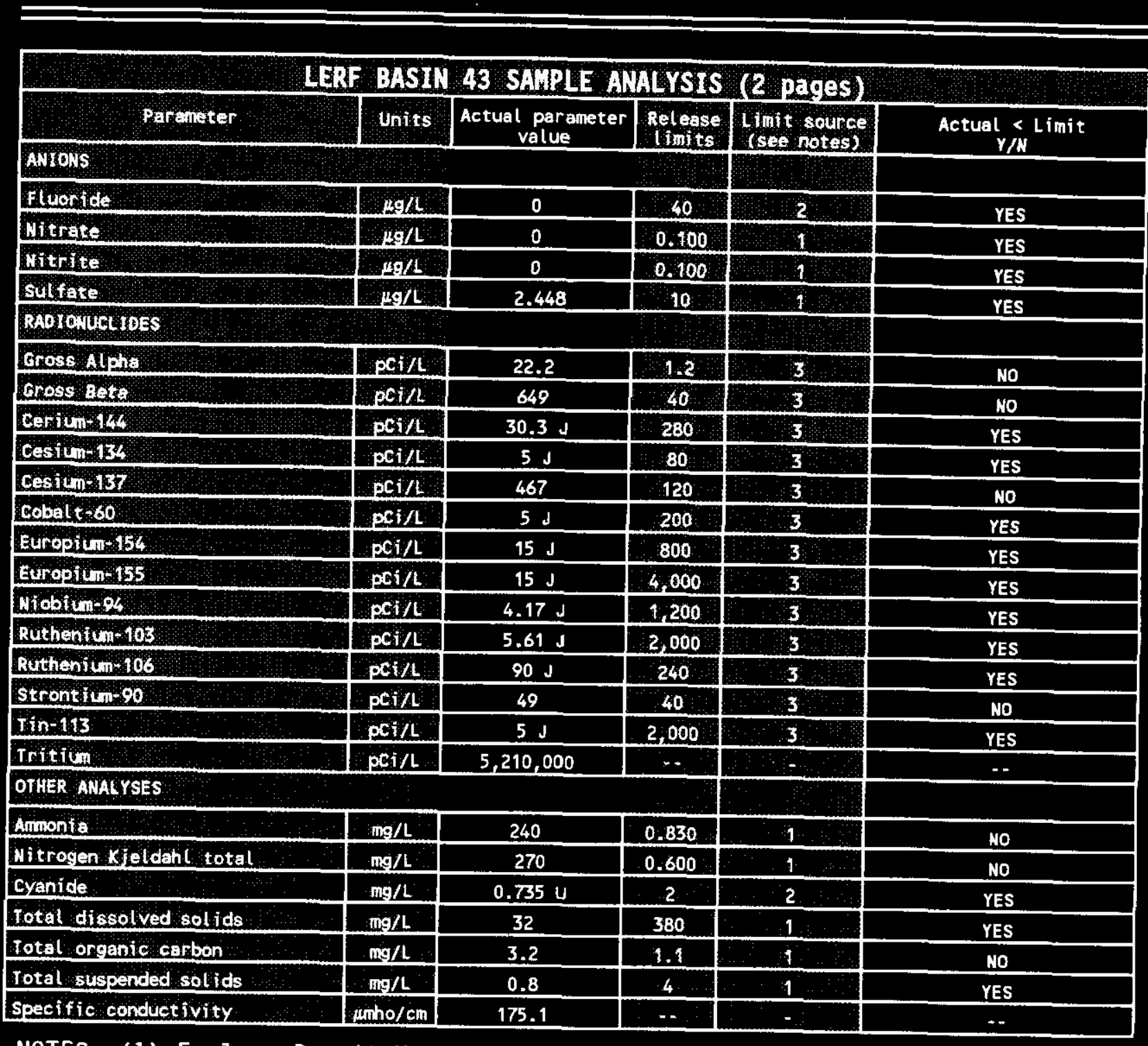

NOTES: (1) Ecology Permit No. ST 4500, dated 6/26/95 (Ecology 1995)

(2) EPA Delisting Approval, dated 6/7/95 (EPA 1995)

(3) DOE order 5400.5 ( $4 \%$ of derived concentration guides) (DOE 1990)

$U=$ undetected

$\mathrm{J}=$ estimate

SAMPLE NUMBER $\quad \underline{\text { L00127 }} \quad$ SAMPLE DATE $\underline{7 / 31 / 95}$

RAD SAMPLE NUMBER $\underline{\underline{\text { LO0078 }}}$ SAMPLE DATE $\underline{\underline{8 / 3 / 95}}$ 